\title{
Improvement of Deltaic Lateritic Soil using River Sand and Cement for use as Pavement Construction Material
}

\author{
D. Imafidon, O. R. Ogirigbo*, J. O. Ehiorobo \\ Department of Civil Engineering, University of Benin, Edo State, NIGERIA.
}

\begin{abstract}
This study examined the effect of mechanical and chemical improvement on deltaic lateritic soils in Warri East in Delta State, Nigeria. Mechanical stabilization was carried out by adding river sand to the natural soil in various proportions, while chemical stabilization was carried out using cement and a mixture of cement and sand. Compaction and CBR tests were conducted on the natural soil before and after stabilization. From the results obtained, it was seen that the mechanical stabilization method improved the strength properties of the soil making it suitable for use as subbase materials, though not as much as the chemical stabilization method or the mixed method of stabilization. It was concluded that using a combination of cement and sand as a stabilizing agent for deltaic lateritic soils can lead to significant reduction in the amount of cement required for soil stabilization thus saving costs.
\end{abstract}

Keywords: natural soil, mechanical stabilization, chemical stabilization, optimum sand content, California bearing ratio, Niger Delta soils

\section{INTRODUCTION}

Several highway pavements in Nigeria are failing as a result of using soil with inadequate engineering strength [1]. As a result, the need for improvement of the engineering properties of such soils has been of paramount concern to highway engineers. The most available soils in a particular location do not always have adequate engineering properties to bear the expected wheel loads [2]. Hence, soil improvement has to be made often, to make these soils better. This led to the concept of soil stabilization, which is any treatment applied to a soil to improve its strength and reduce its vulnerability to water $[3,4]$. If the treated soil is able to withstand the stresses imposed on it by traffic loading under all weather conditions without excessive deformation, then it is generally regarded as stable [5].

There are two main methods of soil stabilization - mechanical and chemical. There are other soil stabilization methods that involve the combination of these two [6]. Mechanical stabilization involves the use of physical processes to improve the soil properties, either by changing the physical composition of the soil by blending it with other soils or by placing barriers in the soil to achieve the preferred effect (e.g. using sod as cover to avoid generation of dust). According to [7], mechanical stabilization done by blending the soil

\footnotetext{
${ }^{*}$ Corresponding author (Tel: +234 (0)813 696 2171)

Email addresses: davidimafidon2@gmail.com (D. Imafidon), okiemute.ogirigbo@uniben.edu (O. R. Ogirigbo), jacehi@uniben.edu (J. O. Ehiorobo)
}

with other soils, is the most cost-effective and beneficial method of soil stabilization. It is when this method of stabilization is not feasible or does not produce the desired result that chemical methods are considered. Chemical method of soil stabilization employs the use of admixtures to modify the chemical properties of the soil to attain the desired properties, e.g. reduction of the soil's plasticity leading to an increase in the soil's strength $[8,9]$. The most common admixtures or chemicals used in this method include lime, cement, fly ash, bituminous materials, ashes of agricultural products, etc. Recently, other non-conventional chemicals like polymers and enzymes have been utilized for soil stabilization [10].

The Niger Delta region is over $70 \%$ riverine and superficially underlain by different soil types, all overlying the deltaic coastal plain sand [2]. These superficial soils include the fine beach sand of the coastal ridge; the extremely soft, compressible and undesirable marine mud or chicoco, of the vast mangrove swamp; the highly montmorillonitic active silty clay soil of the freshwater zone, which swells and shrinks in the raining and dry seasons respectively and the deltaic lateritic soils of the dry flatlands and plains [11]. Of all these soils, only the deltaic lateritic soils have been found suitable for use as subgrade materials in their natural forms or with minor improvement $[2,12]$. Hence, for roadworks in this area, materials are often hauled over long distances to the project sites. The Nigerian Federal Ministry of Works and Housing Highway Design Manual [13] 


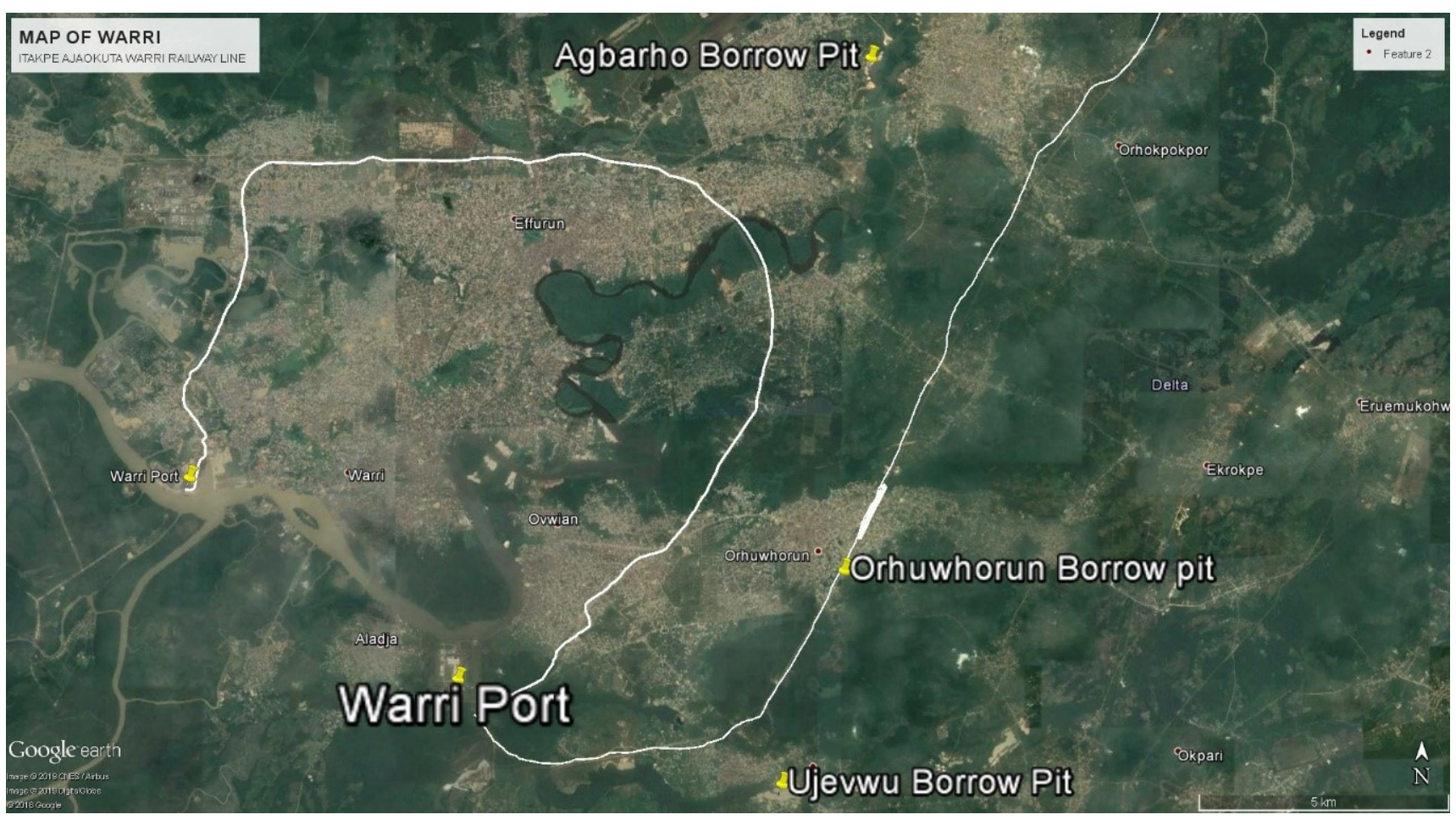

Figure 1: Map showing sampling locations.

specifies that for a material to be suitable for use as subgrade, it must have a minimum CBR of 5\%; while for subbase and base, it must have CBR values of $30 \%$ and $80 \%$ respectively. It would be interesting to see if upon stabilization, these deltaic lateritic soils will be deemed adequate for use as pavement construction materials. A study such as this will be significant for highway design engineers as well as other stakeholders involved in highway projects. Hence, in this study, deltaic lateritic soils obtained from Warri East in the Niger Delta region of Nigeria, was subjected to three different types of soil stabilization methods - mechanical, chemical and a combination of mechanical and chemical stabilization methods, to determine which of these methods is more suitable for use in the improvement of the properties of these soils.

\section{MATERIALS AND METHODS}

\subsection{Study Area}

The study area is Warri, which is located some $40 \mathrm{~km}$ away from the shores of the Atlantic Ocean in the Niger Delta region of Nigeria. The area is a prominent centre of commercial activities in southern Nigeria. It occupies a low-lying area which is drained by Warri River and its network of tributaries and creeks that empties into the Atlantic Ocean. The drainage pattern is dendritic with tributaries branching without preferred orientations. The water table is very close to the ground surface and varies from 0 to $4 \mathrm{~m}$ [14]. This limited ground water level fluctuation reflects the high amount of precipitation (about $2 \mathrm{~m}$ annually) recorded in Warri over the greater part of the year [14]. The samples used in the study were collected from two trial pits (to a depth of $1 \mathrm{~m}$ to $2.5 \mathrm{~m}$ ) close to the Osubi Airport in Agbarho (shown in Fig. 1).

\section{Soil Sampling}

Natural soil samples were obtained from a trial pit that was dug in the sampling location to depths ranging from $1 \mathrm{~m}$ to $2.5 \mathrm{~m}$. The samples were obtained in disturbed form, stored in cellophane bags to prevent moisture loss, and transported to the Geotechnical Engineering laboratory in the University of Benin for testing and analysis.

\subsection{Materials}

\subsubsection{Sand}

The sand used in the study for mechanical stabilization was obtained locally from the sand beaches of Agbarho, which is located around the Warri metropolis in Delta State. The sieve analysis of the sand is as shown in Fig. 2, while other physical properties of the sand are presented in Table 1.

Table 1: Physical properties of sand used for mechanical stabilization.

\begin{tabular}{llc}
\hline Property & Unit & Value \\
\hline Specific gravity & $\overline{\%}$ & 2.63 \\
Optimum Moisture Content (OMC) & 12.20 \\
Maximum Dry Density (MDD) & g/cm3 & 1.63 \\
California Bearing Ratio (CBR) & $\%$ & 12.1 \\
\hline
\end{tabular}




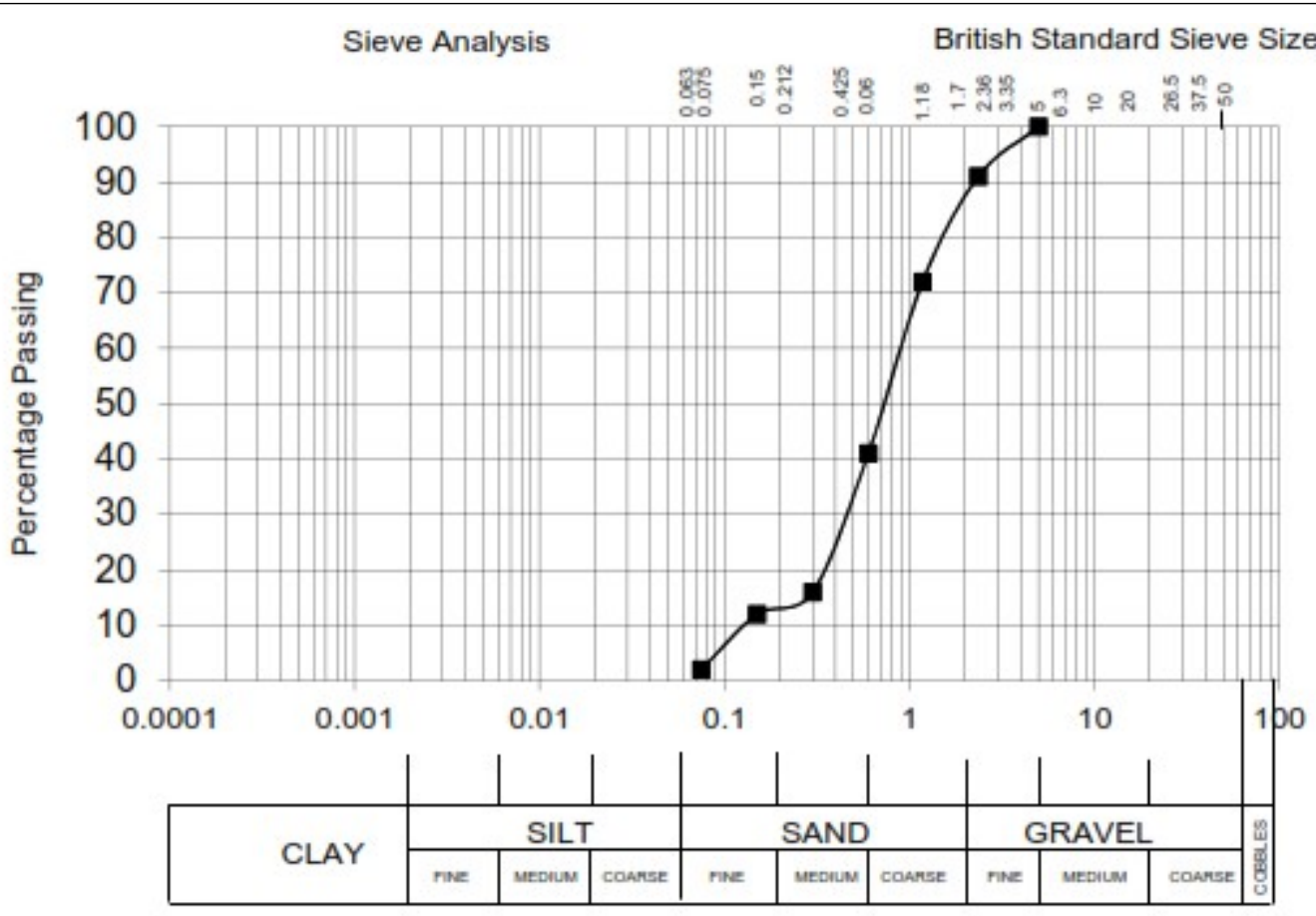

Figure 2: Particle size distribution of sand used in the study.

\subsubsection{Cement}

The cement used in the study was Portland cement. It was obtained from local vendors and conformed to the specifications given in BS EN 1971:2011 [15]. The chemical properties of the cement are presented in Table 2.

Table 2: Physical properties of sand used for mechanical stabilization.

\begin{tabular}{lc}
\hline Property & $\%$ \\
\hline Lime $(\mathrm{CaO})$ & 60.87 \\
Alumina $\left(\mathrm{Al}_{2} \mathrm{O}_{3}\right)$ & 5.36 \\
Soluble silica $\left(\mathrm{SiO}_{2}\right)$ & 20.55 \\
Iron oxide $\left(\mathrm{Fe}_{2} \mathrm{O}_{3}\right)$ & 4.00 \\
Chloride $\left(\mathrm{Cl}_{2}\right)$ & $<0.1$ \\
Magnesia $(\mathrm{MgO})$ & 0.74 \\
Sulfuric Anhydride $\left(\mathrm{SO}_{3}\right)$ & 1.83 \\
Insoluble residue & 2.93 \\
$\mathrm{Al} 2 \mathrm{O} 3 / \mathrm{Fe} 2 \mathrm{O} 3$ & 1.34 \\
\hline
\end{tabular}

\subsection{Stabilization Methods}

Three methods of stabilization were employed in this study - mechanical, chemical, and a mixture of mechanical and chemical.

\subsubsection{Mechanical stabilization}

Mechanical stabilization was carried out by mixing the natural soil samples with sand in various proportions ranging from 0 to $50 \%$ by weight of the natural soil sample. Prior to mixing, the natural soil samples were oven dried for 24 hours and then proportioned with the quartering machine for each mix proportion. The quartered proportions were then mixed together manually on a mixing tray with water starting from $2 \%$ water content, and increasing gradually until the Optimum Moisture Content (OMC) was achieved. Afterwards, samples were then collected for laboratory tests.

\subsubsection{Chemical stabilization}

Chemical stabilization was carried out by addition of cement to the natural soil samples at proportions of $2 \%, 4 \%, 6 \%, 8 \%$ and $10 \%$ by weight of the natural soil sample.

\subsubsection{Mixed method of stabilization}

This mixed method involved addition of cement in proportions of $2 \%$ and $4 \%$, to the mechanically stabilized soil samples. Table 3 gives a summary of the mixing programme adopted for the different methods of stabilization utilized in the study. The control sample is symbolized as 'AGB', while the mechanically and chemically stabilized samples are symbolized as 'AGB-SS' and 'AGB-C' respectively. So for example, a Mix ID of 'AGB-SS10' represents a soil sample where sand has been added to the natural soil in a proportion of $10 \%$ weight of the natural soil; and similarly, a Mix ID of 'AGBC2' represents a soil sample where cement has been added to the natural soil in a proportion of $2 \%$ weight of the natural soil.

\subsection{Laboratory Tests}

Laboratory tests for index properties (moisture content, specific gravity tests, particle size distribution, consistency limits test, compaction test) and strength (CBR) properties were carried out on the natural and stabilized soil samples. The tests were carried out in accordance with the procedures outlined in BS 1377 (parts 1 to 7). 
Table 3: Mix programme for the different methods of stabilization.

\begin{tabular}{lllc}
\hline Stabilization method & Mix ID & Sand (\%) & Cement (\%) \\
\hline None & Control (AGB) & 0 & 0 \\
& AGB-SS10 & 10 & 0 \\
Mechanical & AGB-SS20 & 20 & 0 \\
& AGB-SS30 & 30 & 0 \\
& AGB-SS40 & 40 & 0 \\
& AGB-SS50 & 50 & 0 \\
\hline \multirow{5}{*}{ Chemical } & AGB-C2 & 0 & 2 \\
& AGB-C4 & 0 & 6 \\
& AGB-C6 & 0 & 8 \\
& AGB-C8 & 0 & 10 \\
\hline \multirow{5}{*}{ Mixed method of stabilization } & AGB-C10 & 10 & 2 \\
& AGB-C2-SS10 & 20 & 2 \\
& AGB-C2-SS20 & 30 & 2 \\
& AGB-C2-SS30 & 40 & 2 \\
\hline & AGB-C2-SS40 & 50 & 4 \\
\multirow{5}{*}{ Mixed method of stabilization } & AGB-C2-SS50 & 10 & 4 \\
& AGB-C4-SS10 & 20 & 4 \\
& AGB-C4-SS20 & 30 & 4 \\
\hline & AGB-C4-SS30 & 40 & 4 \\
& AGB-C4-SS40 & 50 & \\
& AGB-C4-SS50 & &
\end{tabular}

\subsubsection{Specific gravity}

This test was carried out using the pycnometer bottle method. The pycnometer is a glass jar of 1 litre capacity that is fitted at its top with a conical cap made of brass. In determining the specific gravity of the soil sample, about $200 \mathrm{~g}$ of oven dried soil sample was placed into the pycnometer and weighed. Thereafter, water is added to the soil sample in the pycnometer till the jar is full, and the weight recorded. The entire contents of the glass jar is then emptied and replaced with water, and the weight also recorded.

The specific gravity of the soil can then be calculated using Eq. (1):

$$
G_{s}=\frac{M_{2}-M_{1}}{\left(M_{4}-M_{1}\right)-\left(M_{3}-M_{2}\right)}
$$

Where $G_{s}$ is specific gravity, $M_{1}$ is weight of empty glass jar, $M_{2}$ is weight of glass jar and dry soil sample, $M_{3}$ is weight of glass jar, dry soil sample and water and $M_{4}$ is weight of glass jar and water.

\subsubsection{Natural moisture content (NMC)}

The test to determine the natural moisture content of the soil samples were performed in accordance to BS 1377-2:1990 [16]. The weight of the wet/natural samples were determined and recorded. Thereafter, the wet samples were placed in the oven to dry at $105^{\circ} \mathrm{C}$ for 72 hours, after which the weight was recorded. The moisture content was then calculated using Eq. (2):

$$
N M C=\frac{M_{w}-M_{d}}{M_{d}}
$$

Where $M_{w}$ is weight of wet soil and $M_{d}$ is weight of dry soil.

\subsubsection{Particle size distribution}

About $500 \mathrm{~g}$ of the soil sample was weighed and wet-sieved to remove clay and silt particles using BS No 200 sieve $(0.075 \mathrm{~mm}$ aperture). After sieving, the soil sample was dried in an oven at $105^{\circ} \mathrm{C}$ for 24 hours. After drying, the standard BS sieves were arranged in descending order of sieve size. The oven dried samples were thereafter sieved mechanically. After sieving the mass retained on each sieve was weighed. The percentages passing each sieve size was calculated and plotted on a semi-log graph - percentage passing vs sieve sizes. The percentage passing per sieve size was calculated using Eq. (3):

$$
\% \text { passing }=\frac{\text { Wt. of soil passing }}{\text { Wt. of soil retailed }} \times \frac{100}{1}
$$

\subsubsection{Consistency limits}

Consistency limit tests were carried out in accordance with BS 1377-2:1990 [16]. The tests carried out under this section were: liquid limit (LL), plastic limit (PL), both of which make up the consistency limit tests. After determining the liquid limit (LL) and plastic limit (PL) of the soil samples, the plasticity index (PI) was then determined. The plasticity index is the difference between the liquid limit and the plastic limit of the soil.

\subsubsection{Compaction}

The compaction test was carried out in accordance with the procedures outlined in BS13774:1990 [17]. The soil samples were first broken up in such a way that the soil particles were reduced to their natural individual sizes. The moisturedensity relationships were then determined using the standard Proctor and the California Bearing Ratios (CBR) $15.24 \mathrm{~cm}$ molds. Two parameters 
are usually obtained from this test - the maximum dry density (MDD) and the optimum moisture content (OMC).

\subsubsection{California bearing ratio (CBR)}

The CBR test was performed by measuring the pressure required to penetrate the soil sample with a plunger of standard area. The measured pressure was then divided by the pressure required to achieve an equal penetration on a standard crushed rock material.

The CBR is calculated using Eq. (4):

$$
C B R=\frac{\text { Measured Load }}{\text { Standard Lord }} \times 100
$$

The standard load at $2.5 \mathrm{~mm}$ and $5.0 \mathrm{~mm}$ penetrations are $13.24 \mathrm{kN}$ and $19.96 \mathrm{kN}$ respectively. The soil samples were tested in the soaked condition to depict the worst case scenario where the pavement materials might be subjected to flooding, as is the case with the coastal areas of Nigeria.

\section{RESULTS AND DISCUSSION}

\subsection{Properties of the Natural Soil Sample}

Table 4 shows a summary of the results obtained from laboratory tests conducted on the natural soil samples obtained from the test location. From the table, it can be seen that the proportion

Table 4: Properties of the natural soil sample as obtained from laboratory tests.

\begin{tabular}{lc}
\hline Property & Value \\
\hline Percentage fines (\%) & 39.3 \\
Liquid limit (\%) & 42.6 \\
Plastic limit (\%) & 21.5 \\
Plasticity index (\%) & 21.1 \\
OMC (\%) & 12.4 \\
MDD (g/cm3) & 1.91 \\
CBR (\%) & 7.0 \\
\hline
\end{tabular}

of materials passing through the No. 200 sieve (75 microns), which was taken as the percentage of fines, was $39.3 \%$. This indicates that the soil in the location contains a fair amount of fines (silt and clay). The liquid limit and plasticity index of the soil are $42.6 \%$ and $21.1 \%$ respectively, which according to Casagrande's plasticity chart, indicates that the soil is CI (clay with intermediate plasticity). According to the American Association of State Highway and Transportation Officials (AASHTO) soil classification guide, the soil can also be classified as an A-6 soil. The soaked CBR of the soil was obtained as 7\%. Comparing this value to those shown in Table 5, which contains the recommended strength of soils to be used as pavement materials according to the Nigerian Federal Ministry of Works and Housing Highway Design Manual [13], it can be seen that the natural soils are only suitable for use as subgrade materials.
Table 5: Specifications for road pavement structural materials [13].

\begin{tabular}{lc}
\hline $\begin{array}{l}\text { Pavement Structural } \\
\text { Component }\end{array}$ & $\begin{array}{c}\text { Minimum value of } \\
\text { Soaked CBR (\%) }\end{array}$ \\
\hline Base course & 80 \\
Sub-base & 30 \\
Sub grade/foundation soil & $5-11$ \\
\hline
\end{tabular}

\subsection{Impact of Mechanical Stabilization on the Properties of the Natural Soil}

Table 6 and Fig. 3 show the impact of the addition of sand on the compaction and CBR results respectively. From the table, it can be seen that

Table 6: Impact of sand addition on the OMC and MDD of the natural soil.

\begin{tabular}{lccc}
\hline Mix ID & Sand (\%) & OMC (\%) & MDD $\left(\mathbf{g} / \mathbf{c m}^{3}\right)$ \\
\hline Control (AGB) & 0 & 12.4 & 1.91 \\
AGB-SS10 & 10 & 9.8 & 2.02 \\
AGB-SS20 & 20 & 9.8 & 2.02 \\
AGB-SS30 & 30 & 9.8 & 2.03 \\
AGB-SS40 & 40 & 9.1 & 2.10 \\
AGB-SS50 & 50 & 8.6 & 1.96 \\
\hline
\end{tabular}

the addition of sand to the natural soil had an immediate impact on the OMC and MDD of the soil. At $10 \%$ addition of sand, there was a decrease of about $20 \%$ in the OMC and a corresponding increase of about 5\% in the MDD of the stabilized soil. This agrees with the findings by [18-20] and can be attributed to the modification of the physical properties of the natural soil by the presence of the sand, thus improving its ability to be well compacted.

At higher percentages of sand addition however, no significant impact was observed on the OMC and MDD, except at $40 \%$ and $50 \%$, where the OMC was seen to decrease to values of $9.1 \%$ and $8.6 \%$ respectively; whereas the MDD was seen to increase to $2.10 \mathrm{~g} / \mathrm{cm}^{3}$ at $40 \%$ sand addition, and later decrease to $1.96 \mathrm{~g} / \mathrm{cm}^{3}$ at $50 \%$ sand addition.

In Fig. 3, it can be seen that the CBR initially increased with the proportion of sand added up to $30 \%$, but thereafter decreased on further addition of sand. The reason for the initial increase in the CBR can be attributed to the change in the physical properties of the natural soil caused by the presence of the sand. According to the Federal Ministry of Works and Housing Highway Design Manual [13], the minimum CBR for materials suitable for use as granular subbase is $30 \%$ (see Table 5). In order to obtain the optimum sand content (which is defined here as the amount of sand that needs to be added to the natural soil to obtain a CBR of $30 \%$ ), the data was fitted into a non-linear cubic polynomial function (indicated by the red line in Fig. 3). Based on the fit, which gave an Adj. $R^{2}$ value of 0.9916 , the optimum sand content was obtained as $20.4 \%$. 


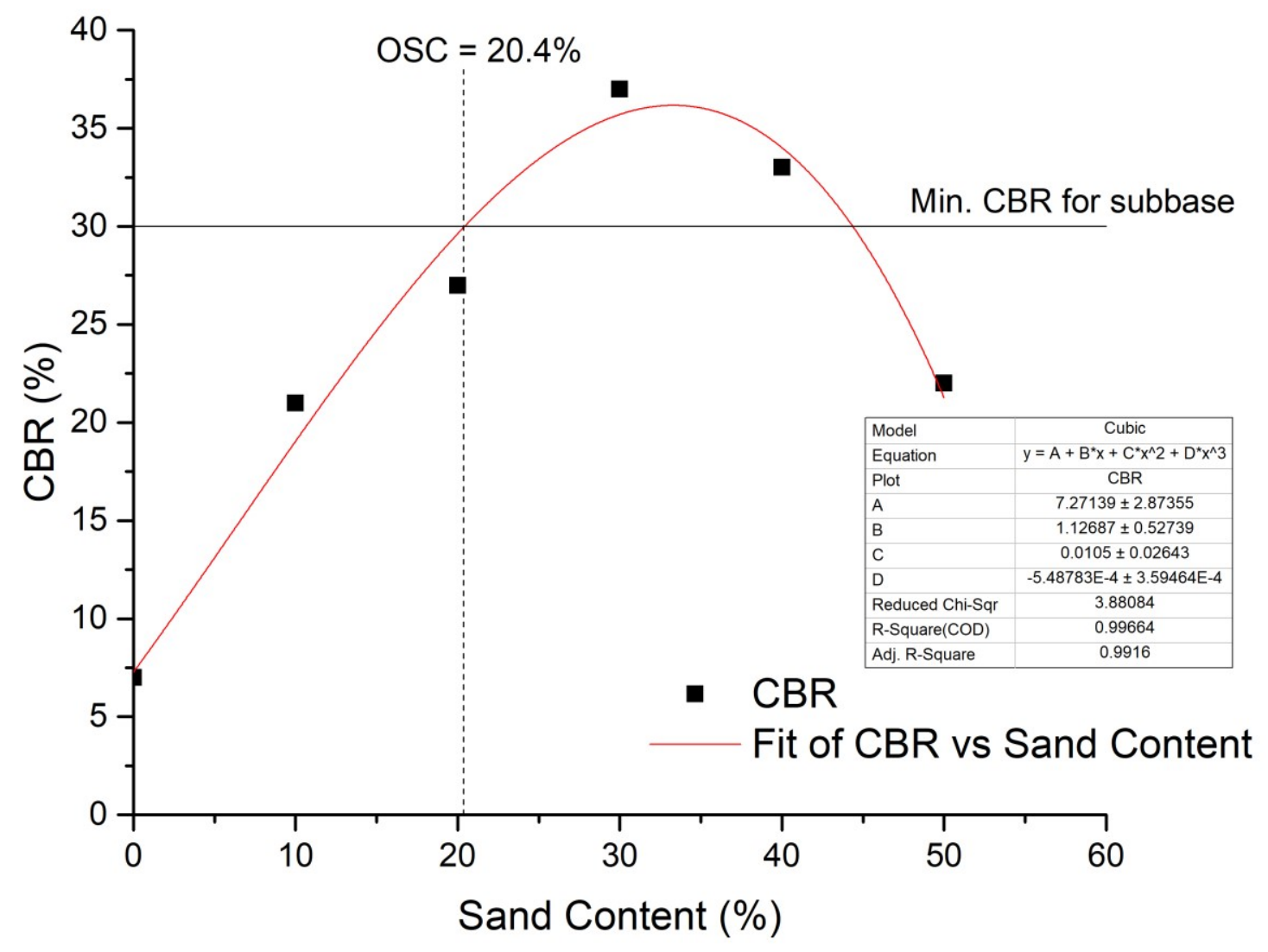

Figure 3: Impact of sand addition on the CBR of the natural soil.

\subsection{Impact of Chemical Stabilization on the Strength Properties of the Natural Soil}

The effect of the addition of cement on the OMC and MDD of the natural soil is presented in Table 7 . It can be seen from the table that with increasing cement percentages, the OMC increases while the MDD decreases. This agrees with the findings of [21-23] and can be attributed to the hydration reaction between the water in the soil and the cement particles, which will continue to occur as long as there are unreacted cement particles and free water within the soil matrix [24].

Table 7: Impact of cement addition on the OMC and MDD of the natural soil.

\begin{tabular}{lllc}
\hline Mix ID & $\begin{array}{l}\text { Cement } \\
(\%)\end{array}$ & $\begin{array}{l}\text { OMC } \\
(\%)\end{array}$ & $\begin{array}{c}\text { MDD } \\
\left(\mathrm{g} / \mathrm{cm}^{3}\right)\end{array}$ \\
\hline Control (AGB) & 0 & 12.4 & 1.91 \\
AGB-C2 & 2 & 13.2 & 1.89 \\
AGB-C4 & 4 & 14.5 & 1.85 \\
AGB-C6 & 6 & 15.0 & 1.84 \\
AGB-C8 & 8 & 15.3 & 1.82 \\
AGB-C10 & 10 & 15.5 & 1.81 \\
\hline
\end{tabular}

In Fig. 4, it can be seen that the CBR increased as the cement content increased. This agrees with previous studies by [9, 25-27], and can also be attributed to the hydration reaction between the cement particles and the water available in the soil. According to [28], during the hydration reaction, cation exchange occurs between the soil particles and the calcium ions in the cement. This results in the formation of hydrated phases e.g. Calcium Silicate Hydrates (C-S-H) that has the ability to aggregate and cement the soil particles together, thereby increasing the strength of the soil matrix.

In order to determine the optimum cement content, two horizontal lines were drawn in the plot of Fig. 4 for 30\% and 80\% CBR. These lines represent the minimum CBR for subbase and base materials according to the Nigerian Highway Design Manual [13]. Thereafter, the data were fitted with a non-linear exponential curve, to give two optimum cement contents of $4.44 \%$ and $9.86 \%$ for subbase and base materials respectively.

\subsection{Impact of Mixed Method of Stabilization on the Strength Properties of the Natu- ral Soil}

Table 8 shows the results of the OMC and MDD as obtained from compaction tests conducted on the natural soil stabilized with the mixed method of stabilization, which involved the combined usage of cement and sand. At $2 \%$ cement addition, the OMC and MDD of the stabilized soil decreased and increased respectively, as the sand content increased. A slightly different trend was observed at $4 \%$ cement addition, in which the OMC of the stabilized soil decreased as the sand content increased; whereas the MDD initially increased at lower sand contents, but decreased at higher sand contents. This is somewhat similar to what was observed in the compaction results of the soil samples that were stabilized by the addition of sand, 


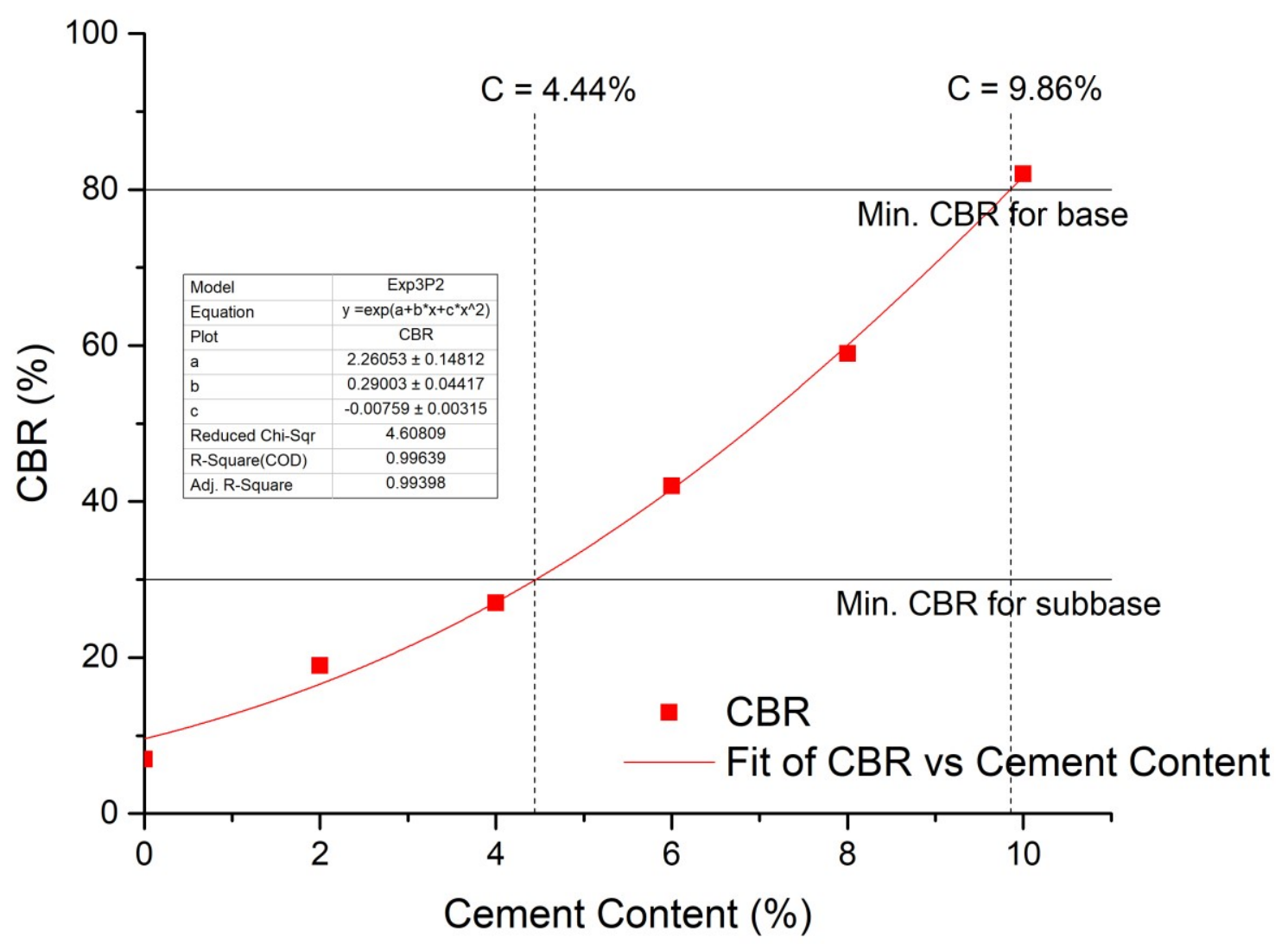

Figure 4: Impact of cement addition on the CBR of the natural soil.

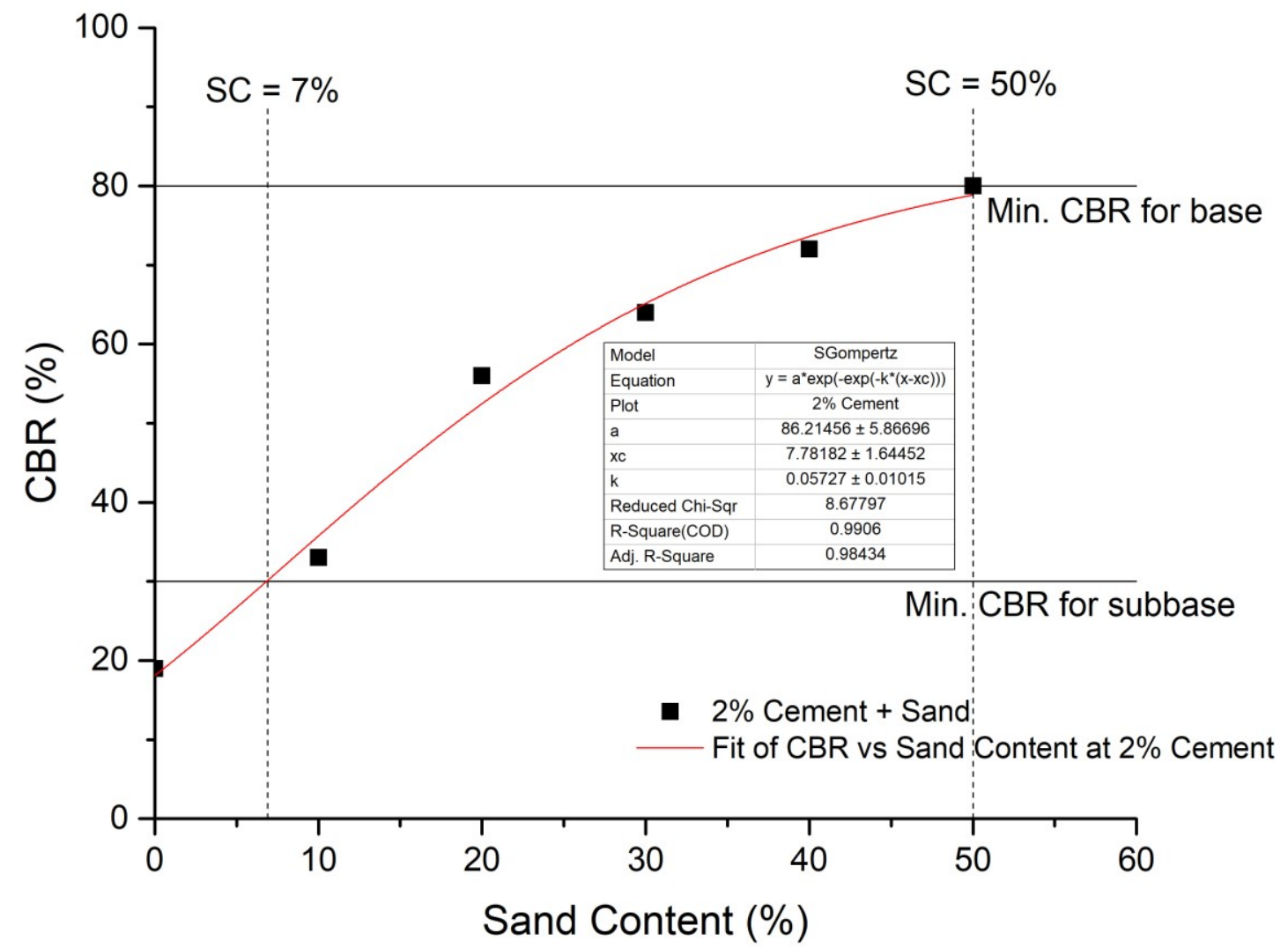

Figure 5: Impact of addition of $2 \%$ cement and various proportions of sand on the CBR of the natural soil. 


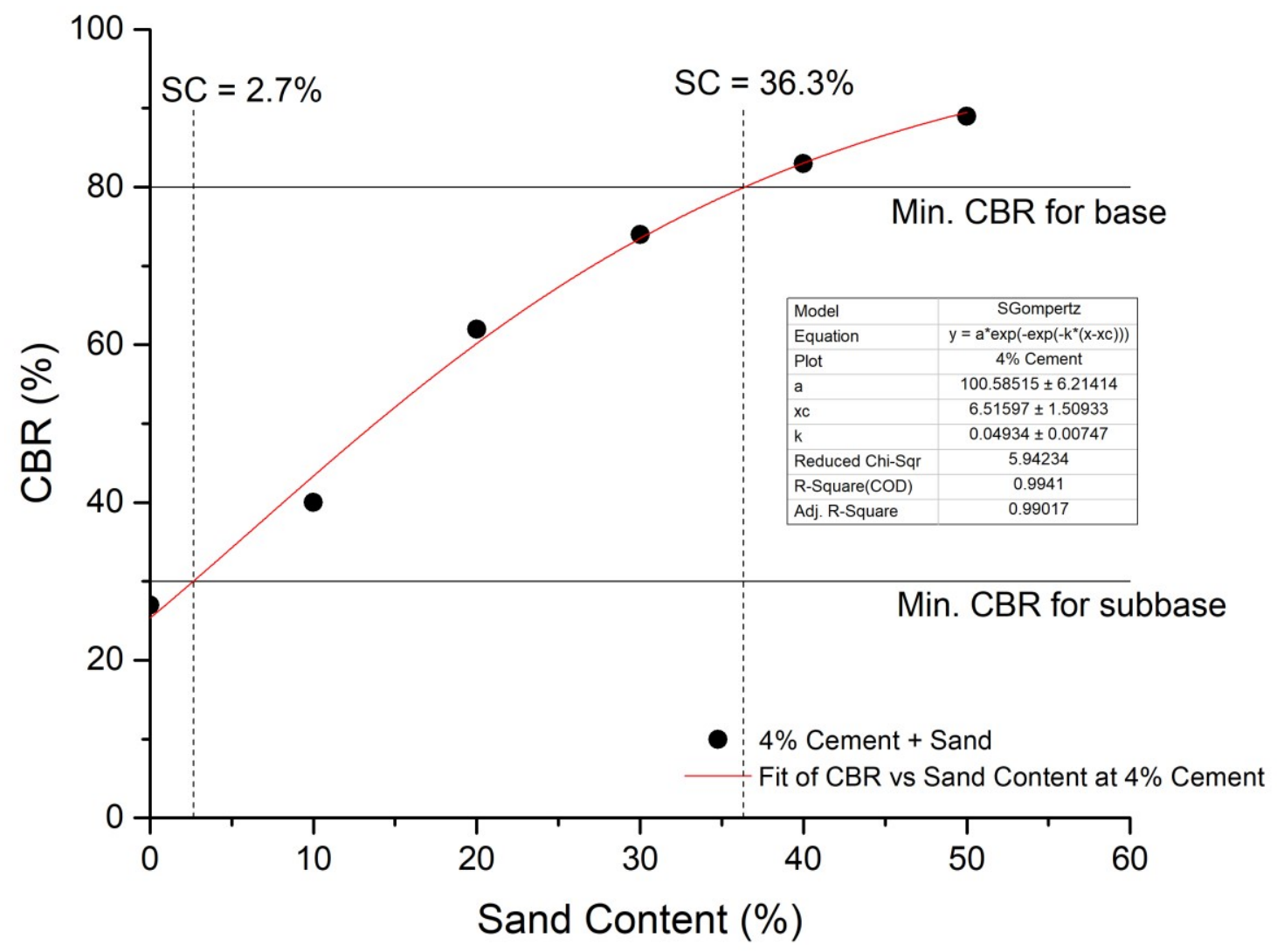

Figure 6: Impact of addition of $4 \%$ cement and various proportions of sand on the CBR of the natural soil.

and seems to suggest that the effect of cement addition on the compaction properties is minimal in the presence of sand.

Table 8: Impact of cement and sand addition on the $\mathrm{OMC}$ and MDD of the natural soil.

\begin{tabular}{lcccc}
\hline Mix ID & $\begin{array}{c}\text { Sand } \\
(\%)\end{array}$ & $\begin{array}{c}\text { Cement } \\
(\%)\end{array}$ & $\begin{array}{c}\text { OMC } \\
(\%)\end{array}$ & $\begin{array}{c}\text { MDD } \\
\left(\mathrm{g} / \mathrm{cm}^{3}\right)\end{array}$ \\
\hline Control (AGB) & 0 & 0 & 12.4 & 1.91 \\
AGB-C2-SS10 & 10 & 2 & 14.4 & 1.90 \\
AGB-C2-SS20 & 20 & 2 & 14.4 & 1.90 \\
AGB-C2-SS30 & 30 & 2 & 13.4 & 1.94 \\
AGB-C2-SS40 & 40 & 2 & 13.0 & 2.00 \\
AGB-C2-SS50 & 50 & 2 & 11.0 & 2.00 \\
AGB-C4-SS10 & 10 & 4 & 12.8 & 1.89 \\
AGB-C4-SS20 & 20 & 4 & 11.8 & 1.92 \\
AGB-C4-SS30 & 30 & 4 & 11.5 & 1.96 \\
AGB-C4-SS40 & 40 & 4 & 10 & 1.90 \\
AGB-C4-SS50 & 50 & 4 & 9.4 & 1.84 \\
\hline
\end{tabular}

The results obtained from CBR tests conducted on the soil samples stabilized by the combination of sand and cement is shown in Fig. 5 and 6. Figure 5 shows the results for $2 \%$ cement plus sand at various proportions, while Fig. 6 shows the results for $4 \%$ cement plus sand. It can be seen from Fig. 5 that when $2 \%$ cement is added to the natural soil, the amount of sand required to produce a material with a CBR of $30 \%$ is about $7 \%$, while that required to produce a material with a CBR of $80 \%$ is $50 \%$. On the other hand, when the per- centage of cement is increased to $4 \%$ (as seen in Fig. 6), the amount of sand required to be added to produce CBR of $30 \%$ and $80 \%$ becomes $2.7 \%$ and $36.3 \%$ respectively. Comparing these values to those in Fig. 4, where it was seen that $4.44 \%$ and $9.86 \%$ of cement was required to attain CBR values of $30 \%$ and $80 \%$ respectively, one can see that the combination of cement and sand as a stabilizing agent can lead to a significant reduction in the amount of cement required for soil stabilization. This is significant because of the environmental issues associated with the use of cement as a construction material, where it has been stated that the production of 1 ton of Portland cement will result in the emission of about $900 \mathrm{~kg}$ of carbon dioxide [29].

\section{CONCLUSION}

This study investigated the effect of using mechanical and chemical methods to improve the properties of deltaic lateritic soils obtained from Agbarho located in Delta South within the Niger Delta area of Nigeria. The mechanical stabilization method involved the addition of river sand to the natural soil at various proportions, while the chemical stabilization method involved the addition of cement to the natural soil at various percentages. A mixed method of stabilization, which involved the addition of cement and sand, was also used. Compaction and CBR tests were conducted on the soil samples before and after stabilization, to determine the effect of the various stabilization 
methods on the strength properties of the natural soil. From the results obtained, it was seen that the mechanical stabilization method improved the strength properties of the soil to making it suitable for use as subbase materials, though not as much as the chemical stabilization method or the mixed method of stabilization. For the mechanical stabilization method, an optimum sand content of $20.4 \%$ was found to improve the CBR of the natural soil to $30 \%$; whereas for the chemical stabilization method, cement contents of $4.44 \%$ and $9.86 \%$ gave CBR values of $30 \%$ and $80 \%$ respectively. For the mixed method of stabilization, a mixture of $2 \%$ cement and sand when added to the natural soil gave CBR of $30 \%$ and $80 \%$ at sand contents of $7 \%$ and $50 \%$ respectively; whereas a mixture of $4 \%$ cement and sand gave CBR of $30 \%$ and $80 \%$ at sand contents of $2.7 \%$ and $36.3 \%$ respectively.

Based on the findings of the study, it is recommended that the mixed method of stabilization, which involves the use of cement and sand, be used for the stabilization of these types of soil. This is due to the fact that it would lead to a significant reduction in the amount of cement used in the stabilization process, thereby making it more environmentally friendly and cost effective.

\section{References}

[1] K. Onyelowe, D. Van, C. Igboayaka, F. Orji, and H. Ugwuanyi, "Rheology of mechanical properties of soft soil and stabilization protocols in the developing countriesNigeria," Materials Science for Energy Technologies, vol. 2 , no. 1 , pp. 8-14, 2019.

[2] A. Tse and A. Ogunyemi, "Geotechnical and chemical evaluation of tropical red soils in deltaic environment: Implications for road construction," International Journal of Geology, Earth and Environmental Sciences, vol. 6 , no. 1 , pp. 19-29, 2016.

[3] H. Afrin, "A review on different types soil stabilization techniques," International Journal of Transportation Engineering and Technology, vol. 3, no. 2, pp. 19-24, 2017.

[4] P. Ghadir and N. Ranjbar, "A review on different types soil stabilization techniques," Construction and Building Materials, vol. 188, pp. 361-371, 2018.

[5] F. Ugbe, "Basic Engineering Geological Properties of Lateritic Soils from Western Niger Delta," Research Journal of Environmental and Earth Sciences, vol. 3, no. 5, pp. 571-577, 2011.

[6] A. Firoozi, C. Olgun, A. Firoozi, and M. Baghini, "Fundamentals of soil stabilization," International Journal of Geo-Engineering, vol. 8, no. 26, pp. 1-16, 2017.

[7] K. Onyelowe and F. Okafor, "A comparative review of soil modification methods," ARPN Journal of Earth Sciences, vol. 1, no. 2, pp. 36-41, 2012.

[8] A. Bello, J. Ige, and A. Hammed, "Stabilization of lateritic soil with cassava peels ash,"British Journal of Applied Science and Technology, vol. 7, no. 6, pp. 642$650,2015$.

[9] D. Eme and K. Ohwerhi, "Characteristics of almond leaf-ash cement stabilized lateritic soil," Nigerian Journal of Technology, vol. 39, no. 3, pp. 701-709, 2020.

[10] M. Mirzababaeia, A. Arulrajahb, and M. Ouston, "Polymers for stabilization of soft clay soils," Procedia Engineering, vol. 189, pp. 25-32, 2017.

[11] E. Akpokodje, "Preliminary studies on the geotechnical characteristics of the Niger Delta sub-soil," Engineering Geology, vol. 26, no. 3, pp. 247-259, 1989.

[12] - "The engineering geological characteristics and classification of the major superficial soils of the Niger Delta," Engineering Geology, vol. 23, no. 3, pp. 193-211, 1987.
[13] "Federal ministry of works highway manual part 1: Design," Volume III: Pavements and Materials Design, 2013 .

[14] A. Oghenero, A. Okey, O. Brume, S. Okunuwadje, and O. Jerry, "Classification and compaction characteristics of lateritic soils of Warri, Delta state, Nigeria," Advanced in Applied Science Research, vol. 5, no. 3, pp. 451-457, 2014.

[15] "Bs en 197-1:2011," Cement - composition, specifications and conformity criteria for common cements. BSI, Brussels, 2011.

[16] "Bs 1377-2:1990," Methods of test for soils for civil engineering purposes. Classification tests. BSI, Brussels, 1990.

[17] "Bs 1377-4:1990," Methods of test for soils for civil engineering purposes. Compaction-related tests. BSI, Brussels, 1990.

[18] A. Roobhakhshan and B. Kalantari, "Stabilization of clayey soil with lime and waste stone powder, Int. Journal of Scientific Research in Knowledge, vol. 1, no. 12, pp. 547-556, 2013.

[19] P. Satyanarayana, P. Raghu, R. Kumar, and N. Pradeep, "Performance of crusher dust in highway plastic gravel soils as road construction material," IOSR Journal of Mechanical and Civil Engineering, vol. 10, no. 3, pp. 1$5,2013$.

[20] A. Bshara, Y. Bind, and P. Sinha, "Effect of stone dust on geotechnical properties of poor soil," International Journal of Civil Engineering and technology, vol. 5, no. 4, pp. 37-47, 2014.

[21] G. Miller and S. Azad, "Influence of soil type on stabilization with cement kiln dust," Constr. Build. Mater., vol. 14 , no. 2 , pp. 89-97, 2000.

[22] F. Sariosseiri and B. Muhunthan, "Effect of cement treatment on geotechnical properties of some Washington States soils," Eng. Geol., vol. 104, no. 1, pp. 119-125, 2009.

[23] A. Idris, A. Abdulfatah, S. Ahmad, and A. Bashir, "Compaction behaviour of lateritic soil modified with cement and rice husk ash for road construction,"Nigerian Journal of Technology (NIJOTECH), vol. 38, no. 3, pp. 573579,2019

[24] T. Khan, M. Taha, A. Firoozi, and A. Firoozi, "Strength tests of enzyme-treated illite and black soil mixtures," in Proceedings of the institution of civil engineersengineering sustainability, vol. 169 , no. 5. Westminster: Thomas Telford Ltd, 2015, pp. 214-222.

[25] A. Pedarla, S. Chittoori, and A. Puppala, "Influence of mineralogy and plasticity index on the stabilization effectiveness of expansive clays," Transp Res Rec $J$ Transp Res Board, vol. 12, no. 3, pp. 91-99, 2011.

[26] K. Onyelowe and F. Okafor, "Portland cement/quarry dust improvement of olokoro laterite for road base," World J. Eng. Sci., vol. 4, pp. 133-143, 2013.

[27] M. Abu-Farsakh, S. Dhakal, and Q. Chen, "Laboratory characterization of cementitiously treated/stabilized very weak subgrade soil under cyclic loading," Soils and Foundation, vol. 55, no. 3, pp. 504-516, 2015.

[28] A. Hasanbeigi, L. Price, H. Lu, and W. Lan, "Analysis of energy-efficiency opportunities for the cement industry in shandong province, china: A case study of 16 cement plants," Energy, vol. 35, pp. 3461-3473, 2010.

[29] D. Little, "Evaluation of structural properties of lime stabilized soils and aggregates," Prepared for the national lime association, vol. 1, pp. 1-89, 1999. 